\title{
Leadership Styles of Industrial Engineers in Pottery Industries in Pampanga
}

\author{
Joana L. Ramos, Sherryl B. Salangsang, Laurence B.Nacpil, GenerS.Subia and \\ Jocelyn B.Cruz
}

\begin{abstract}
The researchers conducted this study which evaluated the leadership styles of industrial engineers in pottery industries in Pampanga in the Philippines. The twenty-six (26) respondents were profiled and the correlation between each characteristic and the three leadership styles: autocratic, democratic, and free-reign (laissez-faire), was computed. After analyzing the results, it was observed that most of the respondents favored a democratic leadership style. Moreover, the researchers draw out that as the young IE supervisors tend to support free-reign leadership less as compared to older IE supervisors.
\end{abstract}

Keywords-Autocratic, democratic, industrial engineering, leadership styles, pottery industries.

\section{INTRODUCTION}

A lot of individuals think that to become a leader in business; one should have some kind of business-focused educational background. But the truth is leaders of several companies share one thing in common: they were all educated in or began their careers in some form of engineering discipline [1].

Many engineers in this day and age are leaders of different industries. Civil, Mechanical, Electrical and Industrial engineers were most likely to be involved in leading their people and in doing crucial decision making.

In this study, the researchers focused on the leadership styles of industrial engineers in selected pottery industries in Pampanga. Pottery has been an important element in the history of the human race, allowing for the storage and transport of a range of materials as well as acting as an artistic medium for thousands of years [2].

In Manila, pottery has been elevated to an art form. Different pottery styles have also been introduced to the urban public through the establishment of pottery schools and regular pottery exhibitions/shows in art galleries. It has captured the upscale market that regularly supports the works by these potters [3].
Making pottery was an early art adeptly practiced in old Pampanga. Earthenware vessels were known in pre-colonial history, and shards have been found in Porac, Lubao, Guagua and Candaba that dates back to the 13th to 16th centuries, a period of active trade with our Asian neighbors. Some have been dated to the Metal Age of Philippine prehistory [4].

Many places in Pampanga were engaged in the pottery industry. This industry helped the province to be economically viable. Industrial engineers who were working as leaders of the pottery industry in Pampanga were the focus of this study. It described their leadership styles. Are they autocratic, democratic or free-reign (laissez-faire) leaders?An autocratic leader is one who takes all decisions himself without consulting the subordinates while the democratic leader encourages his subordinates to participate in the decision-making process and laissez-faire or free rein leader goes a step further and turns an entire problem or project over to subordinates [5].

Specifically, this study aimed to describe the profile of the Industrial Engineers, their leadership styles and the relationship between their profile and their leadership styles. Results of this study may help the owners of the company determine the suited leadership styles in the pottery industry to be able to make accurate and better decisions [6] regarding their business concerns.

\section{METHODOLOGY}

The study used a descriptive correlational research design. According to [7], as cited by [8], "Correlational research is employed to test the degree of relationship between two variables."

The data collection was done in selected pottery industries in Pampanga where in several Industrial Engineers were employed as leaders in their respective departments. These companies manufactured different products but shared a common goal, which is to achieve productivity through effective leadership. 
The respondents of the study were 26 selected engineers in Pampanga. They were chosen purposively based on the following criteria [9]: industrial engineer (IE); and currently were leaders of different departments in pottery industries.

The instrument used in this study was the Leadership Style Survey Questionnaire (LSSQ) by [10]. The LSSQ was utilized to collect data about the perceived leadership styles of Industrial Engineers.Data were collected through the distribution of survey questionnaires to the respondents.
Survey questionnaires are personally handed to the respondents by the researchers.

To organize and summarize the demographic profiles of the respondents and the scores in the LSSQ, descriptive statistics were used. On the other hand, Pearson Product Moment Correlation Coefficients was used to compute the relationship established among the demographic profiles and leadership styles of IEs. SPSS software was employed to process all the numerical gathered data.

\section{RESULTS AND DISCUSSION}

Table 1. Description of the Respondents' Demographic Profiles

\begin{tabular}{r|c|c}
\multicolumn{1}{c|}{ Category } & Frequency & Percent \\
\hline \multicolumn{1}{c|}{ Age (in years) } & & 69.2 \\
\hline $21-30$ & 18 & 15.4 \\
\hline $41 \&$ above & 4 & 15.4 \\
\hline No. of Months in the Company & & 65.4 \\
\hline $12-24$ & 17 & 26.9 \\
\hline $25-48$ & 7 & 7.7 \\
\hline
\end{tabular}

Table 1 exhibits the demographic profiles of the 26 IE supervisors in terms of their age in years and the number of months in the company. Majority of the respondents were still young since they were in the age range of 21-30

Table.2. Determination of Dominant Leadership Styles among Respondents

\begin{tabular}{r|c|c}
\hline Leadership Styles & & \\
\hline Autocratic & 1 & 3.8 \\
\hline Democratic & 19 & 73.1 \\
\hline Free-Reign & 6 & 23.1 \\
\hline
\end{tabular}

Table 2 reflected the individual leadership style preferences of the respondents. It can be observed from the table that majority of the IEs were employing democratic leadership styles and only one is applying an autocratic form of managing their people.

Table 3.Relationship between Demographic Profiles of IESupervisors and theirLeadership Styles

\begin{tabular}{c|c|c|c|c}
\hline \multirow{2}{*}{ Indicators } & Leadership Style & $\begin{array}{c}\text { Pearson } \\
\text { Correlation }\end{array}$ & $\begin{array}{c}\text { Asymp. Significance } \\
\text { (2-tailed) }\end{array}$ & $\begin{array}{c}\text { Verbal Interpretation } \\
\text { (Pearson-r test) }\end{array}$ \\
\hline \multirow{4}{*}{ Age } & Autocratic & 0.036 & 0.86 & Not Significant \\
\cline { 2 - 5 } & Democratic & -0.063 & 0.759 & Not Significant \\
\cline { 2 - 5 } & Free-Reign & $-0.500 *$ & 0.017 & Significant \\
\hline \multirow{2}{*}{$\begin{array}{c}\text { No. of Months in the } \\
\text { Company }\end{array}$} & Autocratic & -0.089 & 0.667 & Not Significant \\
\cline { 2 - 5 } & Democratic & 0.068 & 0.74 & Not Significant \\
\cline { 2 - 5 } & Free-Reign & 0.089 & 0.665 & Not Significant \\
\hline
\end{tabular}

The data suggest that only one engineer takes all decisions himself without consulting the subordinates while the majority of them encourages their subordinates to participate in the decision-making process [5].
$(69.2 \%)$. As to their stay in the company, more than $60 \%$ were in the range of one to two years in their work ( 12 to 24 months ). 
Table 3 revealed the significant relationship that exists between the demographic profile and the leadership styles of the respondents. Pearson Product Moment Correlation Coefficients was used in providing Pearson correlation values, each with its corresponding interpretations (significant or not significant).

Pearson's $r$ correlation is used for the demographic data such as age and number of months in the company because the data gathered were in terms of number or quantitative. In the case of the age of the IE supervisors, it can be inferred from the list of values and their corresponding interpretations, that age was not significantly related to autocratic and democratic leadership styles while it was negatively related to free-reign leadership style. This means that young engineers were more of free-reign leaders, imply ing that they turn an entire problem or project over to their subordinates [5].

\section{CONCLUSIONS}

The researchers concluded that most of the respondents were 21-30-year-old and were working in the Production Department for 12-24 months. It can also be concluded that the majority of them opt for a democratic leadership style.

Moreover, the researchers draw out that as the youngIE supervisors tend to support free-reign leadership less as compared to older IE supervisors.

\section{REFERENCES}

[1] Technologies, Bliley. (2017). Why Engineers Make Great Business Leaders. https://blog.bliley.com/engineers -great-leaders

[2] Pretty, Tom. (2010). The Importance of Pottery in Human Development. https://ezinearticles.com/?TheImportance-of-Pottery-in-Hu manDevelopment\&id=3980794

[3] Ceramic Artist. (n.d.). http://www.hadrianmendozapottery.com/philippines

[4] The Art of Kuran. (February 27, 2011). http://views fromthepampang.blogspot.com/201 1/02/23 9-art-of-kuran.html

[5] Aishwarya, M.(n.d.). Leadership Styles in Management | Business Management. http://www.business managementideas .com/manage me $\mathrm{nt} /$ leadership-styles/leadership-styles-in-managementbusiness-management/18457

[6] Subia, Gener S.(2018). Think Like My Teacher (TLMT): A New Method in Assessing Millennial Learners. International Journal of Arts, Humanities,

and Social Sciences. Volume 3. Issue
1.www.ijahss.com

[7] Patten, M.L. (2002) Understanding Research Methods. Pyrczak Publishing, U.S.A.

[8] Subia, G., Salangsang, L. and Medrano, H. (2018) Attitude and Performance in Ma-thematics of Bachelor of Elementary Education Students: A Correlational Analysis. American Scientific Research Journal for Engineering, Technology, and Sciences (ASRJETS), 39, 206-213.

[9] Subia, G.S. (2018). Comprehensible Technique in Solving Consecutive Number Problems in Algebra. Journal of Applied Mathematics and Physics, 6,447457. https://doi.org/10.4236/jamp.2018.63041

[10] Leadership Style Survey. http://www.nwlink.co m/ donclark/leader/survstyl.htm 1 